PAWEŁ GAŁA*

ORCID: 0000-0002-5446-3436

DOROTA ŁOBOS-KOTOWSKA**

ORCID: 0000-0003-4060-4071

Marek StańKo***

ORCID: 0000-0002-6085-6455

\title{
Konstrukcja gospodarstwa rodzinnego na tle konstrukcji gospodarstwa rolnego w Kodeksie cywilnym i ustawie o kształtowaniu ustroju rolnego
}

\section{Wprowadzenie}

Koncepcja gospodarstwa rolnego oraz gospodarstwa rodzinnego w polskim systemie prawnym to jedna z „osi” wszechstronnych zainteresowań naukowych Profesora Romana Budzinowskiego ${ }^{1}$. Problematyka podjęta w artykule stanowi więc niezwykle trudne i odpowiedzialne zadanie. Oczywi-

* Uniwersytet Śląski w Katowicach.

** Uniwersytet Śląski w Katowicach.

*** Uniwersytet Śląski w Katowicach.

${ }^{1}$ R. Budzinowski, Gospodarstwo rolne jako kategoria prawna-charakterystyka szczegółowa, w: P. Czechowski (red.), Prawo rolne, Warszawa 2019, s. 118 i n.; idem, Koncepcja gospodarstwa rolnego w prawie rolnym, Poznań 1992; idem, Pojęcie gospodarstwa rolnego wedtug kodeksu cywilnego - rozważania na tle art. $55^{3}$ k.c., „Ruch Prawniczy, Ekonomiczny i Socjalogiczny” 1991, nr 3; idem, W kwestii statusu prawnego gospodarstwa rolnego jako przedsiębiorstwa, w: A. Dańko-Roesler, J. Jacyszyn, M. Pazdan, W. Popiołek (red.), Rozprawy z prawa prywatnego. Księga pamiatkowa dedykowana Profesorowi Aleksandrowi Oleszce, Warszawa 2012. 
ście pełna jej analiza nie jest możliwa, toteż konieczne jest skoncentrowanie uwagi na wybranych zagadnieniach, które wydają się pierwszoplanowe.

Celem rozważań jest określenie założeń prawno-konstytucyjnych i ekonomicznych konstrukcji prawnej gospodarstwa rodzinnego na tle konstrukcji gospodarstwa rolnego w Kodeksie cywilnym ${ }^{2}$ i w ustawie z 11 kwietnia 2003 r. o kształtowaniu ustroju rolnego ${ }^{3}$. W artykule zostanie wykazane, że przepis art. 23 Konstytucji RP stanowi jedynie normę kierunkową o silnym zabarwieniu ideologicznym, która tylko częściowo została wypełniona treścią przez ustawodawcę w przepisach ustawy o kształtowaniu ustroju rolnego na potrzeby reglamentacji obrotu nieruchomościami rolnymi. Wydaje się, że jest to rozwiązanie, które powoduje dysfunkcjonalność systemu prawnego, a stan ten pogłębił się jeszcze wskutek kolejnych nowelizacji ustawy o kształtowaniu ustroju rolnego. Taki stan prawny musi rodzić pytanie o kierunek prac nad zmianami w polityce rolnej państwa.

\section{Gospodarstwo rodzinne w Konstytucji RP}

Na wstępie warto przedstawić koncepcję gospodarstwa rodzinnego, która została zarysowana $\mathrm{w}$ art. 23 Konstytucji $\mathrm{RP}^{4}$. Zgodnie z tym przepisem gospodarstwo rodzinne powinno stanowić podstawę ustroju rolnego państwa, przy czym zasada ta nie może naruszać ochrony prawa własności (art. 21) ani swobody prowadzenia działalności gospodarczej (art. 22), która to swoboda może zostać ograniczona w drodze ustawowej i ze względu na ważny interes publiczny. Jak podkreśla się w doktrynie prawa konstytucyjnego, przepis ten nie tworzy żadnego prawa podmiotowego, nie może także stanowić samodzielnej podstawy skargi konstytucyjnej ${ }^{5}$. Warto przy tym zasygnalizować, że współczesne konstytucje niezwykle rzadko formułują odrębne zasady dla ustroju rolnego, tym bardziej oparte na postulacie wyróżnienia gospodarstwa rodzinnego jako podstawy ustroju rolnego państwa.

Zagadnienie to pojawiło się w niektórych konstytucjach w związku z określaniem zasad polityki gospodarczej państwa, w ramach której zaczęto uwzględniać, a jednocześnie wyróżniać problematykę rolnictwa ${ }^{6}$. W polskim

${ }^{2}$ Ustawa z 23 kwietnia 1964 r. - Kodeks cywilny (t.j. Dz. U. z 2020 r., poz. 1740 ze zm.).

${ }^{3}$ Ustawa z 11 kwietnia 2003 r. o kształtowaniu ustroju rolnego (t.j. Dz. U. z 2020 r., poz. 1655 ze zm.; dalej: u.k.u.r.).

${ }^{4}$ Konstytucja Rzeczypospolitej Polskiej z 2 kwietnia 1997 r. (Dz. U. Nr 78, poz. 483 ze zm.).

5 P. Tuleja, w: P. Tuleja (red.), Konstytucja Rzeczypospolitej Polskiej. Komentarz, LEX/ el. 2021.

${ }^{6}$ Por. m.in. art. 44 konstytucji Włoch z 1947 r., art. 93-97 konstytucji Portugalii z 1976 r. czy art. 104 ust. 2 konstytucji Szwajcarii z 1999 r., który - podobnie jak art. 23 Konstytucji RP - nie 
porządku prawno-konstytucyjnym zasada ta uwarunkowana jest po części względami historycznymi ${ }^{7}$. Wydaje się jednak, że przepis art. $23 \mathrm{w}$ swej podstawowej funkcji ma przeciwdziałać tworzeniu gospodarstw wielkoobszarowych jako dominującej formy prowadzenia działalności rolniczej, a także gospodarstw opartych na własności państwowej. Ta ostatnia kwestia wydaje się szczególnie istotna, zważywszy na „spuściznę” prawną sprzed przełomu ustrojowego lat 1989/1990, w której dominująca była - zwłaszcza w pierwszych latach po wojnie - tendencja do upaństwowienia gospodarstw i kolektywizacji rolnictwa.

Zanim zostanie przedstawiona i przeanalizowana funkcja gospodarstwa rodzinnego na tle konstrukcji prawnej gospodarstwa rolnego w ogólności, konieczne jest zarysowanie roli art. 23 Konstytucji RP dla kształtowania ustroju rolnego państwa.

Należy zgodzić się z przyjmowanym w doktrynie prawa konstytucyjnego poglądem, że przepis ten służy podkreśleniu specyfiki ustroju rolnego, a zarazem nakazuje „wmontowanie” tego ustroju w zasady społecznej gospodarki rynkowej ${ }^{8}$. Ponadto, zachowując swoją funkcję gwarancyjną, nie wyklucza on możliwości istnienia innych typów gospodarstw rolnych ${ }^{9}$. Nie ulega również wątpliwości, że art. 23 Konstytucji RP może być postrzegany jako jeden z przepisów wpływających na kierunek polityki państwa i może wyznaczać ustawodawcy zwykłemu cele regulacji, jakie powinny być uwzględniane w przepisach dotyczących ustroju rolnictwa. Ta ostatnia kwestia znalazła odzwierciedlenie także w orzecznictwie Trybunału Konstytucyjnego ${ }^{10}$.

tylko zawiera postulat wspierania przez państwo gospodarstw rolnych, ale także dopuszcza w tym celu ograniczenie wolności gospodarczej.

${ }^{7}$ Por. art. 99 ust. 2 konstytucji marcowej, art. 88 ust. 2 konstytucji kwietniowej czy w okresie powojennym art. 10 konstytucji z 1952 r. (zmieniony i oznaczony jako art. 15 nowelą z 10 lutego 1976 r., zmieniony nowelą z 20 lipca 1983 r., uchylony nowelą z 29 grudnia 1989 r.).

${ }^{8}$ Tak m.in. L. Garlicki, M. Zubik, Teza 3 do art. 20, w: L. Garlicki, M. Zubik (red.), Konstytucja Rzeczypospolitej Polskiej. Komentarz, t. I, Warszawa 2016; A. Bisztyga, Gospodarstwo rolne jako kategoria konstytucyjna. Wyktadnicze uwagi do art. 23 Konstytucji RP, w: P. Litwiniuk (red), Samorząd terytorialny w procesie rozwoju gospodarczego obszarów wiejskich. 25 lat doświadczeń - nowe wyzwania, Warszawa 2015, s. 94-96. Krytycznie do tej kwestii odnosi się A. Oleszko (Uznanie rodzinnego gospodarstwa rolnego jako konstytucyjnej podstawy polskiego ustroju rolnego. Uwagi do Konstytucji z 2 kwietnia 1997, „Rejent” 1997, nr 5, s. 85), według którego „rozchwianie” treści art. 23 jest świadectwem kompromisowości jego ujęcia i wynikiem braku generalnej wizji polityki rolnej państwa.

${ }_{9}$ A. Oleszko, Uznanie rodzinnego gospodarstwa rolnego..., s. 88-89.

${ }^{10}$ Por. wyrok TK z 31 stycznia 2001 r. (P 4/99), w którym Trybunał zakwestionował przepisy szczególne o dziedziczeniu gospodarstw rolnych, zamieszczone w art. 1059 i n. k.c., podkreślając w uzasadnieniu, że ,władze publiczne mają obowiązek podejmowania działań zmierzających do tego, aby prowadzenie gospodarstwa rodzinnego było produktywną formą gospodarowania, 
Warto dodać, że konstrukcja prawno-konstytucyjna gospodarstwa rodzinnego, ale także konstrukcja gospodarstwa rodzinnego w ustawodawstwie zwykłym powinna przynajmniej w podstawowych ramach uwzględniać założenia Wspólnej Polityki Rolnej UE, która przewiduje działania interwencjonistyczne władz państwowych. Na tym tle pojawiły się (m.in. w rozporządzeniu Rady WE nr 2328/91) pojęcia gospodarstwa rozwojowego i gospodarstwa rodzinnego. Chociaż nie przyjęto uniwersalnej definicji tych pojęć, to w orzecznictwie TSUE wskazano, że pojęcia te są używane w różnym znaczeniu, a obowiązek ich precyzyjnego określenia spoczywa na państwach członkowskich ${ }^{11}$. Wskazuje się, że ,,pomimo braku jednolitości gospodarstwa rodzinne definiuje się z reguły jako stanowiące własność rodziny bądź prowadzone przez rodzinę, która dostarcza większość gruntu lub kapitału. W gospodarstwach rodzinnych praca ma być wykonywana przez członków rodziny, jednak siła robocza może być dodatkowo najmowana"12.

Uwzględniając przedstawione na wstępie założenia konstytucyjne, należy zauważyć, że zarysowanie konstrukcji prawnej gospodarstwa rodzinnego na tle konstrukcji gospodarstwa rolnego w k.c. i u.k.u.r. nie jest zadaniem łatwym. Zagadnienie to jest jednak istotne nie tylko ze względu na regulacje krajowe, ale także na uwarunkowania wynikające z członkostwa Polski w Unii Europejskiej. Jak podkreśla się w doktrynie, ten szerszy kontekst normatywny odnoszący się do problematyki prawnorolnej powoduje, że znaczenie regulacyjne podstawowych kategorii pojęciowych i ich kształt będą zależne również od tego, na ile orzecznictwo sądowe wydobędzie z art. 23 Konstytucji RP samodzielne treści, a na ile - przy poszanowaniu założeń krajowego ustroju rolnego - pozostanie zbieżne z celami Wspólnej Polityki Rolnej UE ${ }^{13}$.

\section{Wybrane zagadnienia szczegółowe}

Nie ulega wątpliwości, że określenie kształtu normatywnego gospodarstwa rodzinnego, z uwzględnieniem założeń aksjologicznych wynikających z norm konstytucyjnych, wymaga odniesienia tego pojęcia do kodeksowej definicji gospodarstwa rolnego. Ponadto połączenie konstrukcji gospodar-

a przepisy szczególne o dziedziczeniu gospodarstw rolnych w kształcie przyjętym w kodeksie cywilnym tego nie zapewniają".

${ }_{11}$ P. Czechowski, Proces dostosowywania polskiego prawa rolnego i żywnościowego do prawa UE, Warszawa 2001, s. 128.

${ }_{12}$ C. Banasiński, Konstytucyjne podstawy porzadku prawnego w gospodarce, w: C. Banasiński, J. Oniszczuk (red.), Konstytucja - Trybunat Konstytucyjny. Zbiór studiów, Warszawa 1998, s. 32-33.

13 B. Banaszak, Konstytucja Rzeczypospolitej Polskiej. Komentarz, Warszawa 2009, s. 140. 
stwa rolnego z gospodarstwem rodzinnym w kontekście kształtowania ustroju rolnego w Polsce determinuje w znacznej mierze kierunki ewolucji tego ustroju. Celem ustawodawcy nie może być jedynie zachowanie produktywności gospodarstw rolnych różnego typu, w tym gospodarstw rodzinnych, ale także w ramach zasady zrównoważonego rozwoju zapewnienie ochrony środowiska naturalnego, ochrony walorów klimatycznych danego obszaru i przeciwdziałania procesom degradacji, wynikających m.in. $z$,nadmiernie przemysłowej" produkcji rolnej. W tym zakresie regulacja prawno-konstytucyjna przesądza o tym, w jakim stopniu w ustawodawstwie zwykłym znajdą wyraz odrębne przesłanki dotyczące kształtu i ewolucji prawa rolnego ${ }^{14}$.

Kodeks cywilny po nowelizacji z 28 lipca 1990 r. posługuje się $\mathrm{w}$ art. $55^{3}$ stosunkowo szerokim pojęciem gospodarstwa rolnego. Przyjęte w definicji ujęcie przedmiotowo-funkcjonalne powoduje, że gospodarstwo rolne traktowane jest jako zorganizowany zespół dóbr, pewna jedność gospodarcza złożona z określonych elementów. Gospodarstwo rolne stanowi zatem zorganizowany kompleks majątkowy, który należy traktować jako określoną masę majątkową (mienie). Owa masa majątkowa połączona jest funkcjonalnie, lecz cechuje ją zmienność ilościowa i rodzajowa. Pomiędzy składnikami gospodarstwa rolnego powinna istnieć na tyle silna więź funkcjonalna o charakterze celowym, ekonomicznym, że przesądzałaby o nowej jakości, a nie zbiorze elementów.

Mamy zatem do czynienia nie z klasyczną własnością rzeczy, ale z własnością mienia, nazywaną własnością rolniczą. Funkcjonalne związki między poszczególnymi elementami powinny być na tyle mocne, aby masa majątkowa mogła służyć wykonywaniu działalności rolniczej ${ }^{15}$. W takim ujęciu gospodarstwo rolne stanowi podstawową jednostkę wytwórczą w rolnictwie i jako kategoria pojęciowa jest przedmiotem zainteresowania przede wszystkim nauk ekonomicznych, a dopiero w dalszej kolejności nauk prawnych. W doktrynie podkreśla się, że w języku prawnym gospodarstwo rolne ma zróżnicowaną treść w zależności od przedmiotu regulacji ${ }^{16}$. Definicje legalne określają gospodarstwo rolne, wychodząc albo od zespołu składników (ujęcie przedmiotowe), albo od określonej działalności (ujęcie funkcjonalne).

${ }^{14}$ A. Lichorowicz, Konstytucyjne podstawy systemu rolnego Rzeczypospolitej $w$ świetle artykutu 23 Konstytucji, w: M. Wyrzykowski (red.), Konstytucyjne podstawy systemu prawa, Warszawa 2001, s. 119.

15 Gospodarstwo rolne niekoniecznie musi prowadzić działalność w postaci produkcji roślinnej czy zwierzęcej, aby mieć status gospodarstwa rolnego, za wystarczające należy uznać utrzymanie gruntów rolnych przy zachowaniu norm dobrej kultury rolnej. Por. D. Łobos-Kotowska, Prawne pojęcie osobistego prowadzenia gospodarstwa rolnego, „Przegląd Prawa Rolnego” 2021, nr 1, s. 97-98.

${ }^{16}$ R. Budzinowski, Gospodarstwo rolne jako kategoria prawna..., s. 118 i n. 
$\mathrm{Z}$ reguły ustawodawca traktuje gospodarstwo rolne jako zróżnicowany zakresowo zespół czynników produkcji tworzących zorganizowaną całość gospodarczą i w tym ujęciu nawiązuje do kategorii ekonomicznych ${ }^{17}$. Na aktualny kształt tego pojęcia również w Kodeksie cywilnym wpływ miało nie tylko rozszerzenie składników gospodarstwa rolnego i stopniowe przechodzenie od wąskiej kategorii gruntu rolnego (traktowanego już jako gospodarstwo) do gospodarstwa jako zespołu różnych czynników, ale także przechodzenie od gospodarstwa rolnego jako jednostki własnościowej do gospodarstwa jako zorganizowanej całości gospodarczej, w której kategoria własnościowa jest wtórna. Istotą takiego podejścia do konstrukcji gospodarstwa rolnego było traktowanie składników gospodarstwa nie tylko jako przedmiotu określonych praw, ale także jako instrumentów prowadzenia działalności rolniczej ${ }^{18}$.

W systemie prawa rolnego istnieje kilka definicji gospodarstwa rolnego, ale jedynie definicja zawarta $\mathrm{w}$ art. $55^{3}$ k.c. ma walor ogólny i nadaje znaczenie pojęciu gospodarstwa rolnego nie tylko „na użytek” tego kodeksu, ale i innych aktów prawnych o charakterze prywatnoprawnym, które nie tworzą własnych definicji tego pojęcia. W swoim zasadniczym kształcie definicja ta znajduje również zastosowanie do instytucji prawnych przewidzianych w u.k.u.r.

Bez względu na ujęcie gospodarstwa rolnego jako zorganizowanej całości gospodarczej podstawowe znaczenie, zarówno w ujęciu kodeksowym, jak i w ujęciu u.k.u.r., mają grunty rolne. Chociaż w skład gospodarstwa rolnego wchodzą też inne składniki, m.in. grunty leśne (lasy), budynki, urządzenia inwentarz, zapasy oraz prawa związane z prowadzeniem gospodarstwa rolnego, to właśnie grunty rolne przesądzają o kwalifikacji całego zespołu składników majątkowych jako gospodarstwa rolnego ${ }^{19}$. Z kodeksowego punktu widzenia w definicji gospodarstwa rolnego nie zostało zawarte kryterium własnościowe ${ }^{20}$. Kwestia ta będzie miała istotne znaczenie dla definicji gospodarstwa rolnego zawartej w u.k.u.r.

${ }_{17}$ R. Budzinowski, Koncepcja gospodarstwa rolnego ..., s. 62.

18 Ibidem, s. 77 i n.

19 Por. postanowienie SN z 7 maja 1997 r., II CKN 197/97, „Wokanda” 1997, nr 9, s. 9. Należy jednak zauważyć, że nie spełniają przesłanek definicji kodeksowej gospodarstwa rolnego działy specjalne produkcji rolnej, gdyż są wśród nich takie rodzaje działalności, które są prowadzone bez udziału czynnika ziemi. Na ten aspekt zwraca uwagę J. Bieluk, Działy specjalne produkcji rolnej. Problemy prawne, Białystok 2013, s. 50.

${ }^{20} \mathrm{~W}$ doktrynie prezentowane jest także stanowisko odmienne, który przyjmuje, że w definicji gospodarstwa rolnego mamy do czynienia z kryterium własnościowym w odniesieniu do gruntów rolnych, które to pojęcie jest tożsame z pojęciem nieruchomości rolnej w rozumieniu art. $46^{1}$ k.c., przy czym własność nieruchomości nie może przesądzać o tym, komu przysługuje własność w od- 
Przepis art. $55^{3}$ k.c. nie zawiera również normy obszarowej, zatem obszar gruntu rolnego (nieruchomości rolnej) nie stanowi kryterium warunkującego istnienie gospodarstwa rolnego ${ }^{21}$. Odmienne stanowisko pojawiło się w judykaturze i zgodnie z nim za gospodarstwo rolne uznano jednostkę gospodarczą zorganizowaną na nieruchomości rolnej o takim obszarze, który umożliwia prowadzenie działalności wytwórczej w rolnictwie przeznaczonej na $\mathrm{zbyt}^{22}$.

Jak wcześniej sygnalizowano, kodeksowa definicja gospodarstwa rolnego znalazła odzwierciedlenie w u.k.u.r., z pewnymi modyfikacjami. W szczególności - w przeciwieństwie do regulacji kodeksowej - definicja gospodarstwa rolnego zawarta w art. 2 pkt 2 u.k.u.r. choć odsyła do definicji kodeksowej, to wprowadza dodatkowe kryterium obszarowe. W pierwotnym brzmieniu ustawy kryterium powierzchniowe odwoływało się do powierzchni użytków rolnych, których powierzchnia musiała być nie mniejsza niż 1 ha. $\mathrm{W}$ takim ujęciu odesłanie w tej definicji do konstrukcji kodeksowej nie budziło większych wątpliwości. Po nowelizacji u.k.u.r. w 2019 r. ${ }^{23}$ gospodarstwem rolnym stało się tylko takie gospodarstwo rolne w rozumieniu k.c., w którym powierzchnia nieruchomości rolnej lub łączna powierzchnia nieruchomości rolnych jest nie mniejsza niż 1 ha.

Nie ulega wątpliwości, że rezygnacja z kryterium powierzchniowego odwołującego się do powierzchni użytków rolnych wpływa znacząco na zakres samego pojęcia gospodarstwa rolnego. Ponadto w definicji tej ustawodawca podkreślił, że norma obszarowa 1 ha dotyczy łącznej powierzchni wszystkich nieruchomości i nie ma wymogu, aby co najmniej jedna nieruchomość miała powierzchnię minimum 1 ha. Wydaje się, że w takim ujęciu gospodarstwo rolne w u.k.u.r. w znacznej mierze opierać się będzie na konstrukcji nieruchomości rolnej, co należy ocenić krytycznie. W istocie bowiem ustawodawca oderwał ochronę samego gospodarstwa rolnego od realizacji celów, o których mowa w art. 1 u.k.u.r.

niesieniu do całości - tak A. Stelmachowski, w: A. Stelmachowski (red.), Prawo rolne, Warszawa 2005, s. 59. Najdalej idące stanowisko zakłada rozszerzenie kryterium własnościowego na pozostałe składniki gospodarstwa rolnego - tak M. Ptaszyk, Nowe zasady obrotu nieruchomościami rolnymi inter vivos, „Państwo i Prawo” 1991, nr 7, s. 54.

${ }^{21}$ Tak SN w wyroku z 5 lutego 1998 r., I PKN 511/97, OSNP 1999, nr 1, poz. 19.

22 Tak SN w wyroku z 2 czerwca 2000 r., II CKN 1067/98, OSP, 2001, nr 2 poz. 27 z krytyczną glosą A. Lichorowicza. Stanowisko wyrażone przez Sąd Najwyższy może budzić wątpliwości z uwagi na literalne brzmienie przepisu, jednak trudno odmówić mu racji w sferze postulatywnej. Za gospodarstwa rolne powinny być bowiem uznawane wyłącznie te, które działają w celach zarobkowych, a prowadzona w nich produkcja jest zorganizowana i ciągła.

${ }^{23}$ Ustawa z 26 kwietnia 2019 r. o zmianie ustawy o kształtowaniu ustroju rolnego oraz niektórych innych ustaw (Dz. U. poz. 1080), która weszła w życie 26 czerwca 2019 r. 
W tym ujęciu definicja gospodarstwa rolnego znajdzie zastosowanie jedynie do art. 4a u.k.u.r., który nakazuje odpowiednie stosowanie przepisów u.k.u.r do nabycia gospodarstwa rolnego, z tą modyfikacją, że prawo pierwokupu będzie przysługiwało dzierżawcy całego gospodarstwa rolnego. W istocie więc jedyną przesłanką wprowadzenia do ustawy definicji gospodarstwa rolnego jest zapobieganie omijaniu ograniczeń w nabywaniu nieruchomości rolnych przewidzianych w art. 3 i 4 u.k.u.r. poprzez zbywanie całych gospodarstw rolnych, a nie nieruchomości rolnych wchodzących w skład gospodarstwa. Ponadto, w przeciwieństwie do regulacji kodeksowej, w u.k.u.r. główne znaczenie w konstrukcji gospodarstwa rolnego ma kryterium własnościowe. Wniosek taki jest uprawniony, gdyż sama definicja zawarta w ustawie wprost odwołuje się - w zakresie pojęcia gospodarstwa rolnego - do „własnościowej” konstrukcji nieruchomości rolnej.

Uprawniony wydaje się pogląd, że definicja gospodarstwa rolnego zawarta w k.c., a wprowadzona ze wskazanymi wyżej modyfikacjami do u.k.u.r. nie stanowi wystarczającej podstawy do stworzenia trwałej konstrukcji normatywnej gospodarstwa rodzinnego, spełniającej wymogi współczesnej polityki rolnej. W art. 5 ust. 1 u.k.u.r. ,rodzinnym” nazwane zostało bowiem takie gospodarstwo rolne, które jest prowadzone przez rolnika indywidulanego oraz w którym łączna powierzchnia użytków rolnych jest nie większa niż 300 ha $^{24}$.

Odnosząc tę definicję do art. 23 Konstytucji RP, można mieć wątpliwości co do rzeczywistych intencji ustawodawcy, w szczególności tego, czy tak ujęte w ustawie gospodarstwo rodzinne może stanowić podstawę ustroju rolnego państwa. Wątpliwości te wynikają również z samej funkcji art. 23 Konstytucji RP. W doktrynie prezentowane są różne stanowiska na temat tego, czy przepis ten pełni funkcję jurydyczną regulacji sfery rolnictwa, a jego sformułowania w istocie stanowią wytyczne dla ustawodawstwa zwykłego i obowiązują bezpośrednio wszystkich obywateli, organy władzy i instytucje, czy też ma on charakter klauzuli generalnej, dającej możliwość dowolnej interpretacji. Większość doktryny uważa, że na podstawie art. 23 Konstytucji RP nie można konstruować trwałego modelu ustrojowego polskiego rolnictwa, gdyż ma on wymiar raczej ideologiczny niż prawnoustrojowy ${ }^{25}$.

${ }^{24}$ Dodatkowe modyfikacje dotyczą jedynie ustalania powierzchni użytków rolnych, będących przedmiotem współwłasności, w takiej bowiem sytuacji - zgodnie z art. 5 ust. 2 ustawy - uwzględnia się powierzchnię nieruchomości rolnych odpowiadających udziałowi we współwłasności takich nieruchomości, a w przypadku współwłasności łącznej - łączną powierzchnię nieruchomości rolnych stanowiących przedmiot współwłasności. Ponadto zgodnie z ust. 3 przepis ten ma odpowiednie zastosowania do ustalania powierzchni użytków rolnych będących przedmiotem współposiadania samoistnego oraz współposiadania na podstawie użytkowania wieczystego lub na podstawie umowy dzierżawy.

${ }_{25}$ Por. m.in. A. Łabno, Konstytucyjna koncepcja ustroju rolnego. Analiza na podstawie Konstytucji RP z 1997 roku i ustawy o ksztaltowaniu ustroju rolnego, w: P. Litwiniuk (red.), 
W orzecznictwie Trybunału Konstytucyjnego został jednak zarysowany kierunek, zgodnie z którym art. 23 Konstytucji RP może wyznaczać ustawodawcy zwykłemu cele regulacji. Bez względu na podgląd w kwestii funkcji tego przepisu w tym zakresie definicja gospodarstwa rodzinnego zawarta w art. 5 u.k.u.r. została sformułowana co najwyżej na potrzeby ograniczenia obrotu nieruchomościami rolnymi i nie wskazuje typu gospodarstwa rolnego podlegającego ochronie ustrojowej ${ }^{26}$. Wątpliwości pojawiają się również w odniesieniu do istoty tych ograniczeń. W uzasadnieniu wyroku z 31 stycznia 2001 r. Trybunał Konstytucyjny potwierdził wprawdzie, że gospodarstwa rodzinne są podstawą ustroju rolnego, jednak zwrócił uwagę, że wprowadzanie przez ustawodawcę zwykłego modyfikacji ogólnych reguł dziedziczenia gospodarstw rolnych jest dopuszczalne tylko wtedy, gdy służyć to będzie realizacji zasady ustrojowej wyrażonej w art. 23 Konstytucji RP, przy czym gospodarstwa inne, w tym gospodarstwa wielkoobszarowe, nie mogą być traktowane w sposób dyskryminujący. Wszelkie ograniczenia praw i nakładane obowiązki muszą być zatem rozpatrywane zgodnie z zasadą proporcjonalności.

Jak się wydaje, w pełni uprawnione jest przeniesienie powyższych rozważań Trybunału Konstytucyjnego na grunt ustawy o kształtowaniu ustroju rolnego. W tym kontekście rodzi się pytanie, czy ograniczenia wprowadzone przepisami tej ustawy nie naruszają zasady proporcjonalności. Trzeba bowiem pamiętać, że oparta na art. 23 Konstytucji zasada, iż podstawą ustroju rolnego jest gospodarstwo rodzinne, nie może naruszać postanowień art. 21 i 22 Konstytucji. Pierwszy z tych przepisów (art. 21) zobowiązuje państwo do ochrony własności i prawa dziedziczenia, drugi (art. 22) zezwala wprawdzie na ograniczenia wolności działalności gospodarczej, ale tylko w drodze ustawy i tylko ze względu na ważny interes publiczny. Jednak ograniczenia $\mathrm{w}$ zakresie swobody obrotu nieruchomościami rolnymi stosowane do gospodarstw rolnych, przewidziane przepisami ustawy o kształtowaniu ustroju rolnego, mogą zostać uznane za nieproporcjonalne (nadmierne) w stosunku do celu regulacji.

Należy przy tym zauważyć, że ustawodawca co do zasady nie ogranicza obrotu gospodarstwami rodzinnymi, ale wykorzystuje konstrukcję gospodarstwa rodzinnego do wprowadzenia ograniczeń w obrocie nieruchomościami rolnymi i odpowiednio innymi gospodarstwami rolnymi. Chroniony jest

Kwestia agrarna. Zagadnienia prawne i ekonomiczne, Warszawa 2016, s. 95-97; T. Kurowska, Gospodarstwo rodzinne czy gospodarstwo rozwojowe. Dylematy wyboru, w: S. Prutis (red.), Polskie prawo rolne u progu Unii Europejskiej, Białystok 1998; eadem, Gospodarstwo rodzinne $w$ świetle art. 23 Konstytucji, Częstochowa 2004; A. Oleszko, Uznanie rodzinnego gospodarstwa rolnego..., s. 81 .

26 A. Lichorowicz, Instrumenty oddzialywania na strukture gruntowa Polski w ustawie z dnia 11 kwietnia 2003 r. o ksztattowaniu ustroju rolnego, „Kwartalnik Prawa Prywatnego” 2004, nr 2. 
bowiem w pełni tylko rolnik indywidualny, który nabywa grunty w celu utworzenia lub powiększenia gospodarstwa rodzinnego przy spełnieniu pozostałych przesłanek ustawowych. Z ochrony tej nie mogą natomiast skorzystać rolnicy prowadzący działalność w innych formach prawnych i w oparciu o inne gospodarstwa niż gospodarstwa rodzinne. Wątpliwe jest również to, czy ustawodawcy chodziło w istocie o ochronę samych gospodarstw rodzinnych jako podstawy ustroju rolnego państwa, czy też o wykorzystanie tych przepisów do wprowadzenia restrykcyjnych ograniczeń w obrocie niejako w oderwaniu od kształtowania ustroju rolnego.

Jak podnosi się w doktrynie, u.k.u.r. skupia się na specyficznie rozumianej ochronie ziemi rolniczej, preferując przy tym tradycyjną produkcję rolną ${ }^{27}$. W takim ujęciu rolnik, który nie dysponuje nieruchomością rolną (nieruchomościami rolnymi) o powierzchni co najmniej 1 ha, a prowadzący np. działalność ogrodniczą i korzystający ze szklarni, nie jest rolnikiem indywidualnym w sytuacji, gdyby zamierzał powiększyć swoje gospodarstwo ${ }^{28}$.

Warto zauważyć, że w art. 1 ustawodawca wśród celów ustawy wymienił m.in. poprawę struktury obszarowej gospodarstw rolnych i przeciwdziałanie nadmiernej koncentracji nieruchomości rolnych. Wątpliwości mogą budzić jednak instrumenty prawne, za pomocą których cele te mają być realizowane. Sama kwestia mechanizmów prowadzących do optymalizacji struktury obszarowej gospodarstw rolnych jest jednym z najbardziej kontrowersyjnych zagadnień nie tylko w prawie rolnym, ale także w naukach ekonomicznych. Jak dotąd nie wypracowano jednak metody badawczej pozwalającej określić związek między konkretnym narzędziem prawnym a jego wpływem na zmianę struktury obszarowej gospodarstwa. Co więcej, sygnalizowane problemy definicyjne dotyczące samego pojęcia gospodarstwa rolnego i gospodarstwa rodzinnego, a przede wszystkim wątpliwości co do norm obszarowych nie pozwalają na określenie optymalnej struktury obszarowej ${ }^{29}$. Podobne zastrzeżenia można sformułować wobec kryterium „nadmiernej koncentracji nieruchomości rolnych”30.

Próbę doprecyzowania intencji ustawodawcy ma stanowić preambuła ustawy o kształtowaniu ustroju rolnego. Jednak w przeciwieństwie do więk-

${ }_{27}$ P. Blajer, Pojęcie rolnika indywidualnego w prawie polskim na tle prawnoporównawczym, Kraków 2013, s. 180 i n.; Z. Truszkiewicz, Przeniesienie własności nieruchomości rolnej w świetle ustawy o ksztaltowaniu ustroju rolnego, cz. 2, „Rejent” 2003, nr 11, s. 117 i n.

${ }^{28} \mathrm{Na}$ tym przykładzie błędy regulacji prawnej ukazuje J. Bieluk, Ustawa o kształtowaniu ustroju rolnego. Komentarz, Warszawa 2019, s. 329.

${ }^{29}$ Szerzej: M. Stańko, w: D. Łobos-Kotowska, M. Stańko, Ustawa o kształtowaniu ustroju rolnego. Komentarz, Warszawa 2020, s. 24.

${ }^{30}$ Ibidem, s. 26. 
szości aktów prawnych, w których zamieszczono preambułę, w ustawie tej nie pojawiła się ona w tekście pierwotnym, ale została wprowadzona ustawą nowelizującą z 2016 r. ${ }^{31}$ Powstaje zatem pytanie, czy cele, o których mowa w preambule, przede wszystkim ,wzmocnienie ochrony i rozwoju gospodarstw rodzinnych", mają być realizowane dopiero w wyniku nowelizacji ustawy o kształtowaniu ustroju rolnego, czy też preambuła ta stanowi swoistą rekapitulację założeń ustawy również w jej pierwotnym kształcie. Wątpliwości tych nie rozwiewa wypowiedź ministra rolnictwa i rozwoju wsi, według którego ,preambuła ma służyć wszystkim Polakom, którzy czytają ustawę, aby zwrócić uwagę, jak ważnym problemem jest sprawa ochrony i rozwoju gospodarstw rodzinnych" 32 .

Bez względu na ocenę aspektów prawnych tej preambuły nie wydaje się, aby ustawa w tym kształcie realizowała określone w niej cele.

\section{Podsumowanie}

Przedstawione rozważania skłaniają do sformułowania konkluzji, które powinny stanowić swego rodzaju refleksję nad dotychczasowymi rozwiązaniami prawnymi w zakresie konstrukcji prawnej gospodarstwa rodzinnego.

Przede wszystkim należy zauważyć, że kategoria pojęciowa gospodarstwa rodzinnego służy jedynie reglamentacji obrotu. Jak się wydaje, nowoczesna konstrukcja prawna gospodarstwa rolnego w połączeniu z konstrukcją prawną gospodarstwa rodzinnego powinna stanowić warunek wstępny (podstawowy) kształtowania ustroju rolnego, uwzględniającego zmieniające się zasady polityki rolnej państwa. Deklaracja ustrojowa określona w art. 23 Konstytucji RP, jeżeli ma spełniać funkcję normy kierunkowej, powinna zostać wypełniona stosowną treścią przez ustawodawcę zwykłego, w przeciwnym wypadku pozostanie nic nieznaczącą formą manifestu o charakterze ideologicznym. Niewystarczające jest w tym zakresie określenie w ustawodawstwie zwykłym, w szczególności w ustawie o kształtowaniu ustroju rolnego, jedynie cech przypisywanych gospodarstwom rolnym uznawanym za priorytetowe, bez stworzenia nowoczesnej i odpowiadającej współczesnym wymogom konstrukcji takiego gospodarstwa. Nie wydaje się to jednak możliwe, gdy ustawodawca

${ }^{31}$ Nowelizacja dokonana została ustawą z 14 kwietnia 2016 r. o wstrzymaniu sprzedaży nieruchomości Zasobu Własności Rolnej Skarbu Państwa oraz o zmianie niektórych ustaw (Dz. U. poz. 585).

32 Stenogram posiedzenia sejmowej Komisji Rolnictwa i Rozwoju Wsi, posiedzenie nr 23 z 17 marca 2016 r., s. 43. https://www.sejm.gov.pl/sejm8.nsf/biuletyn.xsp?skrnr= RRW-23 [dostęp: 16.09.2021]. 
nadal będzie traktował tę kategorię pojęciową jedynie jako instrument prawny służący reglamentacji obrotu ziemią rolną.

W pełni należy zgodzić się w tym zakresie z Aleksandrem Lichorowiczem, który stwierdza wprost, że definicja legalna gospodarstwa rolnego zawarta w ustawie o kształtowaniu ustroju rolnego jest ,więcej niż nieudolna"33. Wśród podstawowych mankamentów tej definicji trzeba wymienić brak odniesienia do działalności rolniczej i oparcie definicji jedynie na kryterium powierzchniowym. Nie jest obecnie możliwe pomijanie w zakresie tego pojęcia specjalistycznych rodzajów produkcji rolnej nieopartych na czynniku ziemi. W definicji gospodarstwa rodzinnego - w aspekcie podmiotowym, który opiera się na kategorii rolnika indywidualnego - brakuje także nawiązania do „rodziny” jako podmiotu prowadzącego to gospodarstwo, a zarazem czerpiącego $\mathrm{z}$ tej działalności środki na utrzymanie ${ }^{34}$.

Jeśli gospodarstwo rodzinne ma stanowić podstawę ustroju rolnego państwa, to niewystarczające jest zawarcie tego w przepisie konstytucyjnym, a następnie w preambule ustawy o kształtowaniu ustroju rolnego. Konieczne jest natomiast nie tylko uwzględnianie aspektu reglamentacyjnego w obrocie, ale także postrzeganie gospodarstwa rodzinnego w kontekście zapewnienia bezpieczeństwa żywnościowego kraju w połączeniu ze zrównoważonym rozwojem rolnictwa i obszarów wiejskich. Dotychczasowe rozwiązania prawne w tym zakresie nie pozwalają spełnić tych wymogów.

Warto zauważyć, że w doktrynie, a w szczególności w dorobku naukowym Profesora Romana Budzinowskiego, podejmowane były próby określenia cech konstrukcyjnych nowoczesnego gospodarstwa rolnego. Jak się wydaje, niezbędne jest również sięgnięcie do koncepcji gospodarstwa rozwojowego ${ }^{35}$.

Nie pretendując do rozstrzygnięcia przedstawionych w konkluzjach dylematów, celowe wydaje się podjęcie prac ustawodawczych uwzględniających również zawarte w niniejszych rozważaniach wnioski de lege ferenda. Okazją do ponownego zdefiniowania gospodarstwa rolnego może być zapowiadane rozpoczęcie prac nad kodeksem rolnym. Wiąże się to zapewne z reformą polskiego rolnictwa. Jej kształt powinien być jednak przemyślany, z uwzględnieniem celów, jakie ustawodawca chce osiągnąć. Deklaracje o potrzebie poprawy struktury agrarnej i gospodarstwie rodzinnym jako konstytucyjnej podstawie ustroju rolnego są bez pokrycia, jeżeli nie istnieje pełny program rozwoju polskiego rolnictwa.

33 A. Lichorowicz, Instrumenty oddziaływania..., s. 405; por. uwagi krytyczne: T. Kurowska, Gospodarstwo rodzinne..., s. 54 i n.

34 J. Bieluk, Ustawa o ksztattowaniu..., s. 329.

35 T. Kurowska, Gospodarstwo rodzinne... 


\section{BIBLIOGRAFIA}

Banasiński C. (1998), Konstytucyjne podstawy porządku prawnego w gospodarce, w: C. Banasiński, J. Oniszczuk (red.), Konstytucja - Trybunat Konstytucyjny. Zbiór studiów, Warszawa.

Banaszak B. (2009), Konstytucja Rzeczypospolitej Polskiej. Komentarz, Warszawa.

Bieluk J. (2013), Działy specjalne produkcji rolnej. Problemy prawne, Białystok.

Bieluk J. (2019), Ustawa o kształtowaniu ustroju rolnego. Komentarz, Warszawa.

Bisztyga A. (2015), Gospodarstwo rolne jako kategoria konstytucyjna. Wyktadnicze uwagi do art. 23 Konstytucji RP, w: P. Litwiniuk (red.), Samorzad terytorialny w procesie rozwoju gospodarczego obszarów wiejskich. 25 lat doświadczeń - nowe wyzwania, Warszawa.

Blajer P. (2013), Pojęcie rolnika indywidualnego w prawie polskim na tle prawnoporównawczym, Kraków.

Budzinowski R. (1991), Pojęcie gospodarstwa rolnego wedtug kodeksu cywilnego - rozważania na tle art. $55^{3}$ k.c., „Ruch Prawniczy, Ekonomiczny i Socjologiczny” nr 3.

Budzinowski R. (1992), Koncepcja gospodarstwa rolnego w prawie rolnym, Poznań.

Budzinowski R. (2012), W kwestii statusu prawnego gospodarstwa rolnego jako przedsiębiorstwa, w: A. Dańko-Roesler, J. Jacyszyn, M. Pazdan, W. Popiołek (red.), Rozprawy z prawa prywatnego. Księga pamiątkowa dedykowana Profesorowi Aleksandrowi Oleszce, Warszawa.

Budzinowski R. (2019), Gospodarstwo rolne jako kategoria prawna - charakterystyka szczegółowa, w: P. Czechowski (red.), Prawo rolne, Warszawa.

Czechowski P. (2001), Proces dostosowywania polskiego prawa rolnego i żywnościowego do prawa UE, Warszawa.

Garlicki L., Zubik M. (red.) (2016), Konstytucja Rzeczypospolitej Polskiej. Komentarz, t. I, Warszawa.

Kurowska T. (1998), Gospodarstwo rodzinne czy gospodarstwo rozwojowe. Dylematy wyboru, w: S. Prutis (red.), Polskie prawo rolne u progu Unii Europejskiej, Białystok.

Kurowska T. (2004), Gospodarstwo rodzinne w świetle art. 23 Konstytucji, Częstochowa.

Lichorowicz A. (2001), Konstytucyjne podstawy systemu rolnego Rzeczypospolitej w świetle artykułu 23 Konstytucji, w: M. Wyrzykowski (red.), Konstytucyjne podstawy systemu prawa, Warszawa.

Lichorowicz A. (2004), Instrumenty oddziatywania na strukturę gruntowa Polski w ustawie z dnia 11 kwietnia 2003 r. o ksztattowaniu ustroju rolnego, „Kwartalnik Prawa Prywatnego" nr 2.

Łabno A. (2016), Konstytucyjna koncepcja ustroju rolnego. Analiza na podstawie Konstytucji RP z 1997 roku i ustawy o ksztaltowaniu ustroju rolnego, w: P. Litwiniuk (red.), Kwestia agrarna. Zagadnienia prawne i ekonomiczne, Warszawa.

Łobos-Kotowska D. (2021), Prawne pojęcie osobistego prowadzenia gospodarstwa rolnego, „Przegląd Prawa Rolnego” nr 1.

Łobos-Kotowska D., Stańko M. (2020), Ustawa o kształtowaniu ustroju rolnego. Komentarz, Warszawa.

Oleszko A. (1997), Uznanie rodzinnego gospodarstwa rolnego jako konstytucyjnej podstawy polskiego ustroju rolnego. Uwagi do Konstytucji z 2 kwietnia 1997, „Rejent” nr 5.

Ptaszyk M. (1991), Nowe zasady obrotu nieruchomościami rolnymi inter vivos, „Państwo i Prawo" nr 7.

Stelmachowski A. (red.) (2005), Prawo rolne, Warszawa. 
Truszkiewicz Z. (2003), Przeniesienie własności nieruchomości rolnej w świetle ustawy o ksztattowaniu ustroju rolnego, cz. 2, „Rejent” nr 11.

Tuleja P. (red.), Konstytucja Rzeczypospolitej Polskiej. Komentarz, LEX/el. 2021.

\author{
THE CONSTRUCTION OF A FAMILY FARM \\ IN THE CONTEXT OF THE CONSTRUCTION \\ OF AN AGRICULTURAL HOLDING \\ AS PROVIDED FOR IN THE CIVIL CODE \\ AND IN THE ACT ON SHAPING THE AGRICULTURAL SYSTEM
}

\begin{abstract}
Sum mary
The aim of the article is to determine the legal, constitutional and economic assumptions of the legal construction of a family farm in the context of the construction of an agricultural holding in the Civil Code and in the Act of 11 April 2003 on shaping the agricultural system. It has been shown that the provision of Article 23 of the Constitution constitutes only a system declaration, a kind of ideological manifesto. In order for it to be recognised as a directional norm, it should be filled with the relevant content. A definition of a family farm as formulated in the Act on shaping the agricultural system is not sufficient in this respect. It is necessary to formulate a modern construction of such a holding which will meet the requirements of today. However, the direction of these changes should be carefully planned taking into account the agricultural policy of the state.
\end{abstract}

Keywords: agricultural holding, family farm, agricultural regime

\title{
LA COSTRUZIONE DI AZIENDA A CONDUZIONE FAMILIARE SULLO SFONDO DI QUELLA DI AZIENDA AGRICOLA NEL CODICE CIVILE E NELLA LEGGE SUL REGIME AGRICOLO
}

\section{Riassunto}

L'articolo si propone di definire i presupposti giuridico-costituzionali ed economici della costruzione giuridica di un'azienda a conduzione familiare sullo sfondo di quella di un'azienda agricola nel codice civile e nella legge dell'11 aprile 2003 sul regime agricolo. Nell' articolo è stato dimostrato che la disposizione dell'art. 23 della Costituzione è solo una dichiarazione politica, una sorta di manifesto ideologico. Affinché sia riconosciuta come norma direzionale, il legislatore ordinario dovrebbe completarla con contenuti adeguati. A questo proposito, non è sufficiente basare la definizione di un'azienda a conduzione familiare sulla necessità di limitare la compravendita degli immobili agricoli prevista nella legge sul regime agricolo. È necessario creare una costruzione moderna e al passo con i requisiti attuali. I cambiamenti dovrebbero andare in una direzione attentamente studiata, tenuto conto della politica agricola dello Stato.

Parole chiave: azienda agricola, azienda a conduzione familiare, legge sul regime agricolo 